\title{
Early Dutch Exploits in the Western Archipelago of the Indies: In Praise of Equal Partnerships
}

\author{
INGRID S. MITRASING \\ Leiden, Netherlands \\ ingrid.mitrasing2@gmail.com
}

Published online: 20 December 2018

To cite this article: Mitrasing, I.S. 2018. Early Dutch exploits in the western archipelago of the Indies: In praise of equal partnerships. KEMANUSIAAN the Asian Journal of Humanities 25(Supp. 1): 59-82, https://doi.org/10.21315/kajh2018.25.s1.4

To link to this article: https://doi.org/10.21315/kajh2018.25.s1.4

\begin{abstract}
In this article I investigate both what we can know about Dutch ways of dealing with the important ports in the western archipelago, a commercially rich and politically divided region, and what we think we know. I take a fresh look at the beginnings of their presence and at how relations were established and evolved. By employing a critical assessment of the documents produced during this period and comparing these with the scholarly findings in the historical literature, I aim to present an informed perspective of the nature of the different relationships. The documents have at least the merit of being contemporary and therefore reflect perceptions and conditions during this period. Closing alliances and treaties with the rulers of these ports was one way to break the Portuguese trade monopoly which ultimately led to rewriting the region's narrative on the familiar lines of conquest.
\end{abstract}

Keywords and phrases: deceptions, partnerships, strategies, treaties, western archipelago

\section{Introduction}

There runs a support line, so to speak, in Dutch attitude towards the region's important ports, in the early decades of the 17 th century. It was a conduct strategy, inspired by the events following the violence against the Zeeland fleet in Aceh in 1598. The ideas put forward at that crucial period of the encounters, hint at a long-term perspective, a meaningful constant in Dutch policy with regard to their presence in the region. The building and breakdown of relations, that formed and informed their concerns, are the focus of this paper, which is based on a close examination of the extant primary sources. I do not use theoretical methods in assessing the developments, but move towards "an idea of all things transitoriness in history", as worded by the Dutch historian, Meilink-Roelofsz $(1962,30)$. 


\section{A False Start}

It seems paradoxical that the tragedy suffered by the Zeeland expedition in Aceh in 1599 prompted an understanding of friendship and alliance between the Dutch Republic (officially named the United Republic of the Netherlands) and the ruler of Aceh, Sultan Alau'd-din Ri'ayat Shah (r. 1589-1604). The visit started on a high note and ended abruptly with the murder of Admiral Cornelis de Houtman and 28 members of his crew in a vicious attack by an Acehnese mob on board the ships. Frederick de Houtman, the younger brother of the admiral and captain of one of the two ships, together with 22 of his mates were captured when they were ashore. The survivors narrowly escaped with the two ships, losing the two pinnaces to the Acehnese.

Did the Acehnese cry victory over this event? This question and why and how on the ruins of this tragedy a new dawn broke, need probing the documents pertaining to the expedition. It is unfortunate that no Acehnese documentation survived to compare with the European documents. Having noted this, it seems incongruous that the European texts of the expedition found no appreciation from historians who did not bother to analyse the events these documents describe, instead making comments and drawing easy assumptions. Thus, scholars have not highlighted the issues conducive of agitation and instigation in this volatile region, where ideas and interests jostled and joined. As a result thereof, its history of European presence, has been treated fractionally, and even imaginary. Subsequent historians, without qualms put the blame of the brawls and violence against the Amsterdam expedition in Bantam on Java in 1596 and the Zeeland expedition in Aceh on Sumatra in 1599 on the Dutchmen themselves, dodging the facts that the Portuguese were present in both places and incited the rulers against the pirates from Holland. Many see in Cornelis de Houtman who lost his life in Aceh, the trouble shooter, whose abrasiveness caused the mishap in both Bantam on his first voyage and in Aceh. He entered the history books as the offender. Historiography is resolute. Curiously, the Portuguese escaped the historians' scrutiny.

The complex politics in this region entrenched the way of life of its peoples; Aceh was the sworn enemy of Portuguese Malacca, until in 1593 the enemies agreed on trade relations allowing each other's merchants to reside in their respective ports. Aceh and Johor, the successor state to the fallen Malacca sultanate, were enemies from the time Johor succumbed to the Portuguese who manipulated its compliance. Their enmity is regarded as primordial rivalry for trade and political power. The argument put forward in the literature to explain the differences and difficulties between these sultanates is Aceh's imperialism versus Johor's protection of the 
ports. The real issues behind the invasions and subjugations, fission and fusion, did not draw the historian's attention. Relations in the region were complicated by shifting alliances.

Through this avenue of entanglements of loyalties and animosities, newcomers such as the Dutch, unfamiliar with the local ambiguities, needed to chart their way and in the process experienced that the local peoples were at the mercy of their rulers.

The violence against the Zeeland fleet happened when the ships were set to leave the following day on a war expedition with the Acehnese armada, to attack Johor. Its collaboration was in exchange for a shipload of pepper, half of which would be delivered after the return from the expedition, as agreed in writing between Sultan Alau'd-din Ria'yat Shah and de Houtman (Unger 1948, 47). It is a clue to the reasons for the attack. A legitimate question is: was the fleet fitted out with armoury for a military operation? Its aim certainly was to buy spices, such as pepper for which Sumatra was well known, yet it was no secret that merchant ships carried arms. The Amsterdam fleet to Bantam was supplied with ordnance by the States of Holland, the governing institute of the two provinces called Holland, not to be confused with the States General of the United Republic. From the instructions for de Houtman, one reads that the Zeeland fleet carried arms for defensive use only.

Aceh was the most powerful local polity and possessed a mighty maritime force, but the Dutch possessed faster ships. Their collaboration was not per se necessary, but useful to impress the neighbourhood, especially the ports inclined to Johor, showing that Aceh engaged on friendly terms with a new kind of Europeans. The merchants on the other hand were solely led by their aim to load their ships with pepper. The sultan said to de Houtman: "As touching your merchandize, it shall be thus: I have warres with the King of Ior, you shall serve me against him with your ships; your recompense shall be your lading of pepper; this was agreed" (Unger 1948).

The locals were forbidden to sell their pepper to the visitors, leaving de Houtman no option but to agree with the proposal. Perhaps de Houtman's greatest mistake was, that he let himself be manipulated for pepper's sake, to participate in local warfare, outrageously ignorant of the wider implications of his collaboration in a region that was terra incognita. He did not want to go back to his directors, holding office in the town of Veere in the province of Zeeland, without pepper. The Amsterdam expedition to Bantam, in which he was enlisted, took a toll on its company both financially and in human lives. 
An older generation of historians prefer to describe Aceh and its ruler as primitive and hostile, physiognomies that delivered the murderous attack. It however bespeaks a persistent "Orientalist" treatment of revealing east to west. They separated themselves by defining others, withdrawing to an assured position, not contributing to a fruitful discussion. In this connection, it is important to look at the two key pieces of information, the journals of the Englishman John Davis, chief navigator of the expedition and of Frederick de Houtman.1 These talk about the particulars of the harbour procedures such as the measuring of foreign ships, the exchange of ostagiers (hostages), the arrival of the royal tsiap (stamp) required for landing, the splendid reception at the court, the various conversations with the sultan, whose knowledge of the battle between the English and the Spanish armada surprised John Davis and whose unconcealed adoration for the English queen who had gloried over the Spanish, offers a view of his resentment against the Iberians, even if he allowed traders from Portuguese Malacca to reside in his port. In 1580 Spain and Portugal were united under one crown, yet they were autonomous in several fields. Davis mentions that four Portuguese ships under Alfonso Vicente arrived in the harbour "to prevent our trade as the sequel doth shew". I have analysed elsewhere (Mitrasing 2011, 75) why in 1593 Aceh and Malacca finally came to an understanding after almost an entire century of hostilities and wars between them.

According to de Houtman, the Portuguese walked in and out of the palace, meddling in state affairs. They were ecstatic when they saw him chained, calling it a day to celebrate. His vivid description of his perilous life in captivity - with occasion to write a Malay-Dutch grammar, his ordeal under Islamic law and the royal resolution by which he was in the end set free from execution by sword for not converting to Islam, unwaveringly confessing his Christian faith, give us the first evidences of the sultanate. One perceives of a rather well-ordered society with its own idiosyncrasies. It was cosmopolitan through trade and faiths, where the making of weapons was introduced, gold crafting was established and where produce was traded in the markets, chief among these was pepper, as well as silk and benzoin, bartered against foreign goods like Indian textiles, Chinese porcelain and Moluccan spices.

Significant is Davis' account of the attack: the crew sensed that something was seriously wrong when a group of well-armed men with the shahbandar (principal harbour officer) in front entered the ships: "We, mistrusting some treachery, filled our tops with stones, made fast our gratings and prepared our weapons whereat our Baase (boss) was exceedingly angry, commanding all to be dissolved, but we would not" (Unger 1948). 
The instructions for the admiral explicitly stated that he should refrain from bloodshed and aggressive actions, not allow armed locals on board the ships and use force only in case of serious threats (Unger 1948, 51). He relied on his good relationship with the sultan with whom he had long conversations. They agreed on the terms for the expedition to Johor, Aceh's local enemy and Portuguese Malacca's unhappy neighbour, several times forced by the Portuguese into an unholy alliance. Alau'd-din confided in de Houtman that Alfonso Vicente incited him against the Dutchmen but he would not listen.

There is also the fact to consider that de Houtman complained against the sudden steep rise in the price of the pepper; the sultan said to him that he left the business of trade to his shahbandars with whom he should deal. These men acquired more prominence with the developing international trade. They belonged to the elite group known as orangkaya, whose loyalty was vital to rule without dread for losing one's throne.

The Portuguese skilfully manipulated the politics of their old enemy Aceh. Manuel Lobato even speaks of Portuguese diplomatic intervention in Bantam and Aceh (Marques 2000, 55-56). The conclusion can be drawn that the Portuguese, fearing that the balance of power would tilt in Aceh's favour in case Johor was subdued, deliberately obstructed the war expedition, inciting the authorities by spreading the message that de Houtman had fought with the people in Bantam and was not to be trusted.

\section{Diplomacy Unfolding}

There was barely time to digest the news of the violence, before the Dutch were back in Aceh. Van Caerden arrived in 1600 to negotiate a contract for the pepper trade. He was quite successful in striking a deal, but resentful towards the shahbandar who made him pay much more for the pepper than initially agreed and made changes in the contract. Van Caerden molested vessels on their way to Aceh and pillaged their goods. ${ }^{2}$ Important is the fact that he brought a letter from Prince Maurice of Nassau, the commander of the army of the United Republic, for the sultan, who rejected to accept it, incited - as the report goes - that it was written on pig skin (de Jonge 1865-1964, vol. II, 231-232). Despite this rejection, the prince pressed forward almost gleefully. He immersed himself in the overseas expeditions. The special mission he sent to the sultan in 1601 to talk peace was well received and this time his letter was accepted.

In Maurice's letter to Alau'd-din, the "murderer", who was admittedly, the most powerful ruler in the Straits, alliance forming was foregrounded. Striking an 
alliance with the nemesis of Malacca to dispel the Portuguese from there, seemed a matter of practical politics; Maurice was known to be a great military strategist and politician.

He explains the long tyranny of Spain in the United Republic and calls the Iberians, "our common enemy", offering the sultan friendship and assistance against them in exchange for the immediate release of Frederick de Houtman and his mates and not less important, for contracts in the pepper trade, ending his letter with "I kiss the hand of your Majesty, Your servant". ${ }^{3}$ Such effusive letters are valuable to gain insight in the diplomatic communication between the foreign and local rulers. This particular letter between Dutch authority ${ }^{4}$ and the ruler of Aceh, is a proposal for an equal partnership, a fact overlooked by scholars who insist that relationships were unequal, dictated by the Europeans. Alau'd-din's request to de Houtman for assistance in exchange for a shipload of pepper also expresses the idea of an equal partnership.

Cajoled by the offer of friendship and alliance from the prince, the highest commander of the army of a republic governed by aristocracia as explained by Cornelis de Houtman, Sultan Alau'd-din, in an unexpected move, sent three envoys to meet the prince with the returning fleet (1601), which also carried Frederick de Houtman and his mates home at last. It was a demonstration of his trust in the prince. He was apparently ready to enter into an alliance against the deceitful Portuguese who still molested Muslim vessels on their way to Aceh and incited the port of Aru on Sumatra's east coast against him. Alau'd-din had, after all, broken with the war campaigns against Malacca that occupied almost the entire 16th century and allowed Portuguese traders in his port.

The envoys were bystanders in a sea battle in front of the island of St. Helena, between the Dutch ships and the St. Jago, a large Portuguese galleon on its way from Goa to Lisbon, richly laden with Chinese porcelain and other valuables, over which the Dutch claimed victory. They dropped the crew on the Isla de Noronha off the coast of Brazil and brought the St. Jago in triumph to the port of Middelburg, where its cargo was divided and sold. To this occasion a special coin was minted.

The States General, the highest institute of the Republic, keenly turned the visit of the Acehnese mission into an affair of political weight by inviting several European courts to send their representatives to meet the ambassadors of one of the most powerful rulers in Asia. Given the complexity of the political situation in Europe with Spain still a menace, with the arrival of representatives of these courts, the Republic stood sovereign. Spain was still present in the Netherlands even years after several provinces had declared their independence in 1581 . The Iberians were 
not a little alarmed to see the contours of a new political configuration in Asia being drawn.

\section{A Watershed Year}

The United Dutch East India Company (Dutch: Vereenigde Oostindische Compagnie, VOC) was founded in 1602 out of the private companies, by Charter from the States General, giving it the exclusive rights to appoint governors, erect forts, wage wars and maintain a military force in the designated area. The company even paid the bill for the visit of the Aceh mission which left the Republic after circa 15 months, having toured several provinces and visiting Prince Maurice in his military camp in the town of Grave. It was the year the English received the Great Privilege from Sultan Alau'd-din. William Lancaster arrived in Aceh with four tall ships, having as his navigator the same John Davis of the Zeeland fleet. The Privilege allowed the English to trade toll free in the ports of Aceh as a token of great respect for their valiant queen (Elizabeth I). Again we note Alau'd-din's inclination to the northern Europeans, defying the Portuguese. The French too arrived and traded free of taxes in the port. Aceh was open for trade with Europe. Dutch fleets arrived in brief succession in the Straits, demonstrating to the Portuguese that they had come to stay. Van Spilbergen in cooperation with Lancaster attacked a Portuguese ship and pillaged its contents; Van Heemskerk took the Santa Catarina with its rich cargo in 1603 which he brought to Bantam in the island of Java. The universal reaction to the capture of Portuguese ships by the Dutch, is one of unreserved condemnation. They are regarded pirates and the young, brilliant Dutch lawyer Hugo Grotius who laid the basis for international law, as their patron who, as Martine van Ittersum irrevocably writes:

Legitimated their criminal actions, basing and writing his theories in his De Jure Praedae from a perceived nefarious Portuguese conspiracy. The Dutch attestants' sworn statements were corroborated by the conversations with the local rulers of Bantam and Aceh who were too happy to play along, which led to a radical reinterpretation of the history of early Dutch voyages to the East Indies by Grotius. (van Ittersum 2006, 82)

Van Ittersum's outright rejection of the historical validity of the journals of John Davis and Frederick de Houtman, fails to take into account the remarkable strength of the texts themselves so crucial for contemporary understanding of the political configuration at a precise moment. Further, the rulers she mentions, were perfectly able of adding local and individual memories and experiences to the conversations. Her claim that the statements were uncritically incorporated by Grotius into De Jure Praedae is false. 
It is hardly surprising that in the world of the Tordesillas Treaty (1494) which divided the world beyond Europe between the Iberians, over which the Pope stood and in view of their own experiences, the Dutch were unyielding in pursuit of their interests, attacking those who for a century had profited from the Asian trade and violated their rights to partake in it. By seizing Portuguese ships they eventually robbed the Portuguese of their sanctified destiny; the struggle between Catholics and Protestants in Europe was not over and Spain still occupied parts of the United Republic.

\section{Symbol and Substance}

The understanding of friendship and alliance had little meaning for the VOC if it was not arranged by treaty. Good intentions lacked substance in the face of third party interventions. An Akkoord (treaty) was brokered on 17 January 1607 by Olivier de Vivere, vice admiral of Cornelis Matelieff's large fleet which came to the Straits on a military mission to conquer Malacca and the successor of Alau'd-din, Sultan Ali Ri'ayat Shah (r. 1604-1607) (Heeres 1907, vol. I, 48). It is remarkable that the entry regarding Dutch assistance against the Iberians (Article 10) was formulated in very general terms; it did not stipulate the conquest of Malacca and the spoils of war. Rather curiously it speaks of peace with the enemy, which was allowed only by mutual consent. Given the fact that de Vivere was the vice-admiral of a military fleet, the lack of a military strategy is rather incongruous, especially since they had not been successful to conquer Malacca, fighting the Portuguese instead in a fierce sea battle. The presence of the fleet in front of Aceh, however, stopped the Portuguese from Goa, from further invading Aceh in 1606. It may have proven to the Acehnese that their alliance with the Dutch was working. De Vivere made sure that Dutch demands were firmly embedded in the treaty, such as the acquisition of a place for their ships to rendezvous and to settle a colony of families under Dutch jurisdiction. In addition they acquired exclusive trade privileges. Article 4 speaks of the requirement for traders of all nations, including Dutch private traders, to carry het bescheydt van onsen Koningh, a written permit of our King (Prince Maurice) to trade in the ports of Aceh. Intriguing is the fact that the treaty stipulated that the vassals of the States General of the United Republic, coming from whatever place, should be permitted in Aceh. Did they foresee an empire in the far corners of the globe? It looks as if the treaty was meant to be in place "for eternity", which in the Dutch language translates as eeuwiglijck, a word and also a notion appearing in the correspondence, when referring to negotiating treaties and partnerships.

Het bescheydt mirrors the Portuguese cartaz, the written permit which was needed to travel and trade in their extended sphere of interest. The document 
contains interesting information on how to solve religious disputes. This is the only reference I found which specifically refers to religion. The Dutch were not out to spread Christianity; the saying that they were merchants and missionaries does not apply for the period and area under investigation. The conclusion can be drawn that the VOC was decidedly working towards its own sphere of interest. The stance of the orangkaya from the very start of the Europeans' visits in their port, was one of overt opposition against the far-reaching privileges they were given; previously de Houtman, van Caerden and Lancaster experienced problems and changes in the conditions. It may have contributed to the sultan's downfall in 1607.

Admiral van Heemskerk was the first Dutchman to pay a visit to the Sultanate of Johor in 1603. The Portuguese had prevented Aceh's possible subjugation of Johor in 1599 in collaboration with de Houtman. As it became clear, Johor was vital as a strategic partner to conquer Malacca. Before the treaty with Aceh was negotiated, admiral Matelieff himself concluded a treaty with the Yang di Pertuan Alau'd-din Riayat Shah II, the ruler of Johor and his youngest brother Raja Bongsu in May 1606 to conquer Malacca (Heeres 1907, vol. I, 37). Raja Bongsu was destined to play a remarkable role in the politics of Johor as can be noted further in this paper. It was a military treaty. If successful, the VOC would receive autonomy over the walled city and be exempted from paying taxes to a higher authority. Johor acquired the outer areas and territories and would take possession of the Portuguese armoury. The VOC would acquire a place for its ships to rendezvous. Because Malacca was not conquered by Matelieff, the treaty lost its validity and a second treaty was concluded in September that same year, giving the VOC still the right to choose a place for constructing a fort in a place within Johor's jurisdiction. It was only in 1615 that envoy van der Dussen choose the Carimun islands for this purpose. The Gentlemen XVII (the Board of the VOC) were surprised to learn that Johor was chosen, for they saw no profits "in that corner" where they had suffered significant losses (see further). Their negative consideration did not interfere with the friendship with Johor as becomes clear from the developments. At the same time they proposed to abandon several useless forts and to vacate offices to diminish the costs for the company (Colenbrander 1919-1953, vol. IV, 324). This seems an odd decision given the fact that rivals and enemies could take possession of these buildings. It however shows a precise moment of the VOC's presence in the Indies; within a decade and a half it was apparently able, physically and financially, to erect several forts.

Sultan Sri Perkasa Shah Alam as he was known to his contemporaries (r. 16071636) and to us by his posthumous title Iskandar Muda (Alexander Junior), denied the treaty signed by his predecessor, immediately after he ascended Aceh's throne several months later in 1607 . The merchants who came to his port in 1609 to 
start implementing the treaty were dumbfounded to learn of its redundancy. The Privilege of the English became redundant too. At that moment a military fleet under the command of admiral Verhoeff was sheltering in the bay of Aceh, on its way to attack Malacca. Verhoeff was not interested to meet the new sultan to discuss a strategy of attack, but directed his course to Johor to solicit the sultan's assistance for the attack. Iskandar Muda was surprised that his "confederate" did not visit him (Mitrasing 2011, 107).

Back in Europe, a truce between the United Republic and Spain was pending. Iskandar Muda was notified of this in a letter from Prince Maurice which was handed to him by the merchants. His remarkable reply to the prince was that he fully understood that the close proximity of Spain was the reason for the truce and regretted that Aceh was too far from the United Republic to assist in continuing the war, reiterating Aceh's stance against the Portuguese who were the enemy of Islam, saying that he went on with the struggle of his forefathers to pursue them in eternity, no matter what the prince decided. ${ }^{5}$

It was a courteous reply from a ruler who was new to the throne and charted his own course, showing his resoluteness. His rejection of the treaty was clearly not in answer to the pending truce; it was plain that its implementation would be a threat to Aceh's sovereignty. The dangers it posed for its safety were not imaginary, the Portuguese had shown their frame of mind when they attacked Aceh in 1606 for its friendship with the northern Europeans. Although the treaty stipulated that peace with the enemy was only allowed by mutual consent, the truce was decided soon after its signing. Prince Maurice was under heavy pressure to relinquish to an armistice. Whatever the misgivings, the prince informed the sultan of the changing politics.

The VOC stood with empty hands. Iskandar Muda nevertheless expected that military assistance against the Iberians would be delivered unconditionally. $\mathrm{He}$ rallied behind the notion of an alliance between his grandfather and Prince Maurice. The VOC looked not differently at this asking contracts for the pepper trade in return for its assistance. They both had different views on the issue of assistance. This had to be paid for and involved huge sums. It became a contentious issue between the two, which translated itself in mutual resentment. The sultan asked cash and valuable gifts in return for contracts. He became extremely demanding and unpredictable, refusing the company contracts to trade on Sumatra's west coast at the exclusion of the English, who showered him with priced gifts such as a large cannon from King James. But they were repulsed by his insatiability. 
The wrath of the VOC was openly directed towards the English, who were getting the overhand in the pepper trade of Sumatra. There were clashes between them in Aceh's territorial waters and in front of the port of Patani, where the Dutch opened one of their first offices in 1601. They were not prepared to give in to the sultan's excessive demands while they were expected to assist in driving away the Portuguese. Iskandar Muda knew extremely well that they wanted to conquer Malacca for their own sake. They were not only policing the Straits.

VOC ships did not come to Aceh for at least two years starting from 1612. This embargo came in place because these were not given licenses to trade on the west coast. Iskandar Muda was enraged, for spices and porcelain did not come from the Moluccan islands, hampering the trade in his port. His ships stood ready to fire at VOC ships coming too close to the ports. One shot was fired. It was just a warning shot.

\section{The Grip}

The frantic efforts of the VOC for the trade in the Indies were driven by internal and external dynamics. In 1615 the Gentlemen XVII issued a resolution known as Het Principael Hoofdpoinct van onse handel (Principal Headpoint of Our Trade), a blueprint to monopolise the Asian trade, by driving away the Portuguese, English, French, Chinese, Indians, Javanese and Malay from Banda (in the Spice Islands) and those places where the Company obtained contracts and built forts (Colenbrander 1919-1953, vol. IV, 332). The Resolution preserves an important contribution to Dutch imperialism. The infrastructure of power and markets in Asia became the VOC's geopolitical strategy, ultimately its manifest destiny.

Jan Pieterszoon Coen, the first acting director-general of the company business at Bantam (1614-1619), was the initiator of this plan which the Gentlemen XVII adopted. Its implementation became Coen's fixation. He bolstered friendship with the rulers of Aceh, Johor and Patani, important ports, to spin maximum profit for the company.

Putting his ideas and actions under the lens one reads a tale of bravado, petulance and persistence. His approach and that of successive authorities to conducting their relations with the most powerful ruler in the Straits, the sultan of Aceh, rested on the agreed notion "Better a dead friendship with the Atchijnder than war with him" (Colenbrander 1919-1953, vol. VII). It was a demanding strategy, a limiting and challenging factor in their considerations and action preparedness. The pejorative Atchijnder was used for Iskandar Muda, the ruler who embarrassed and infuriated them most. He had, after all, rejected the treaty of 1607 . He became the kingpin, 
drawing the trade of the subdued ports to the port of Aceh, ruling by decrees and levying tolls.

More fundamentally, the vested opinion "Aceh is the enemy of our enemy and therefore our friend" became the guiding principle for the VOC in these relations until the enemy was crushed in Malacca in 1641.

The VOC was busy on two fronts: geopolitics and trade, inspired by Prince Maurice. A network of able clerks and merchants translated the letters from the different ports before these were sent to the Gentlemen XVII in Amsterdam. Malay became the language they started to use to communicate in the ports. The grammar Frederick de Houtman wrote in captivity, may have supported these efforts.

Even when the relationship between the VOC and Aceh was at a nadir and Iskandar Muda had literally called the Dutch and English the beggars of Europe who should not knock on his door but go somewhere else, when the Anglo/Dutch Defence Treaty for the Indies had come into being in 1620, to form a cohesive stance against the ports, the Gentlemen XVII resolved that Aceh and Patani should not be completely deserted, but continued with less cash and personnel, "out of friendship rather than for insignificant profits" (Colenbrander 1919-1953, vol. IV, 538). This doggedness rested flatly on the fact that Aceh did not give up its struggle against the Portuguese, who remained a strong factor in the Straits. Aceh's armada was the largest in Asia of the time, consisting of several fleets located strategically in three ports on the island of Sumatra. It was a massive war machine with a staggering army, which could amount to 40,000 men according to the French admiral de Beaulieu (1621) (Lombard 1996). The Portuguese were in awe of the Acehnese war ships describing these as "bigger than ours". Patani was important as a pepper port in its own right which Iskandar Muda had not subdued. It was also a strategic port in the South China Sea.

\section{Friendship and Connectivity}

The VOC supplied Sultan Abdallah Ma'ayat Syah of Johor (r. 1614-1623) who was the vassal by subjugation of Iskandar Muda, with arms seized from Portuguese ships to defend himself against Aceh. The company acted its balancing footwork, in fact not without success. When it was allowed by Abdallah in 1615 to build a fort in the Carimun islands off the coast of Johor, the Acehnese representative in Johor gave his accord, even if in 1613 VOC merchants who were visiting Johor, took up arms against the Acehnese invaders who came to castigate Johor for its armistice with Malacca of 1610. The Acehnese took 22 Dutchmen as prisoners of war to Aceh together with members of the royal family, one of them was Raja 
Bongsu, the later Sultan Abdallah Ma'ayat Shah and thousands of the common people. Notwithstanding the VOC's close friendship with Johor, Coen was not happy with his merchants' actions against the invading Acehnese. As the directorgeneral of the business, he was setting out the course for the company.

Of interest is the fact that the laxamana, the commander of the armada, requested from the Dutch crew on board their ship De Hoop which was anchored in the river to the principal town of Batu Sawar, not to interfere and they would suffer no harm. Yet the Dutch were more inclined to Johor. Bongsu and the Dutch were friends since admiral van Heemskerk visited Johor in 1603. From then on he implored their assistance to remove the Portuguese from Malacca and remained committed to them. They regarded him as a true friend. His brother, Sultan Alau'd-din Ri'ayat Shah became wary of the Dutch whose efforts to remove the Portuguese from Malacca had hopelessly failed, while admirals and envoys arrived in succession, each with different proposals. He preferred good neighbourship with Malacca to advance Johor's trade, having the support of his orangkaya. The brothers differed in their political stance, yet Bongsu agreed to an armistice with Malacca in 1610 which the Portuguese forced upon them by blockading the Johor river for a whole year (1609), not allowing vessels to leave or come to Johor.

The day after the Johor delegation went to Malacca to sign the document, Bongsu paid a secret visit to merchant Obelaer, deeply apologetic for the fact that he had no option but to agree to the armistice, declaring from the heart that he would never forsake the Prince of Nassau (de Jonge 1865-1964, vol. III, 79-80, 90). He was devastated when he read the letter from the prince which Obelaer handed him, about the pending truce between the Republic and Spain. As mentioned, Portugal and Spain were under one crown. The truce is known as the Twelve Years Truce (1609-1621). In his reply to the prince, he wrote "to whom shall we now turn to give us back Malacca? Now that a peace treaty with the king of Spain is pending, help us to retrieve Malacca so that the world shall praise the name of our brother (Prince Maurice)" (de Jonge 1865-1964, vol. III, 20).

He shows his annoyance with the fact that several admirals came in succession to Johor each with his own proposals and demands. He forthrightly asked the prince to send a person with more authority to make a permanent agreement. Interestingly, it is a proposal for diplomacy at a time when the diplomatic relations were not regulated.

Bongsu stood alone, pushed into an armistice with Malacca, apologetic to Prince Maurice and at the same time betrayed by the Dutch. Iskandar Muda on the other hand was his own master, as shown from his reaction to the news of the pending 
truce between the Republic and Spain. He could afford a sovereign stance from a safe distance from Malacca.

When Bongsu was back in Johor from his captivity in Aceh and acted as the vassal of Iskandar Muda, envoy van der Dussen came to express governor-general Reynst's condolences with the loss of his city (to Aceh) and unabashed asked for compensation for the losses the VOC had suffered when Aceh invaded Johor in 1613. Since 1610, a governor-general functioned as supreme head of the Indies.

Bongsu, detached, responded firmly that the Dutch had betrayed him while it was their duty to defend him and his country, referring to the treaty of $1606 . \mathrm{He}$ reminded van der Dussen that he had lost his country and people and could not be held responsible for the losses of the VOC (Tiele 1886, 70-79). Examining the treaty, there is no mention made of assistance against Aceh. The Dutch captives also maintained to Iskandar Muda that they felt obliged to defend Johor against Aceh.

When many years later Iskandar Muda asked the VOC to deliver him Abdallah (Bongsu), who traded openly with the Portuguese in his refuge in Lingga, the authorities were indignant and flatly refused this, even though they had warned him to stop this practice. It was a perpetuated friendship with a sultan in exile whose grandfather lost Malacca to the Portuguese, while he lost Johor to Aceh.

When he became the director-general of the business in 1614, Coen immediately lifted the embargo on Aceh which he perceived as counterproductive, preferring a dead friendship with the Atchijnder instead of war with him. This would become a constant in his policies. Iskandar Muda released his Dutch captives in 1614 together with Raja Bongsu; he too seemed cautious not to start a war with a steadfastly powerful VOC which had shown its muscles with the embargo. Profiting from the absence of the Dutch in Aceh, the English enjoyed some lucrative trade by bringing Indian textiles, bartering these for pepper and other products.

In 1613 the visiting English general, Thomas Best, handed to Iskandar Muda a seized Portuguese vessel with all the goods and people in it, which he demanded. He left Aceh as orangkaya putih (white nobleman).

Even if Coen loathed Iskandar Muda for his tyrannical behaviour and especially for the fact that he favoured the English "who did not lift a finger to fight the Portuguese", he accused his merchants of all things that went wrong in Aceh, ranting about their incapability to judge the local situation and act accordingly. However, a letter of 1615 sent by director Berchem in Aceh to the authorities in 
Bantam, included a request for more cash and goods, explaining that they were ridiculed by the locals for not delivering on their promises and regarded as petty traders.

\section{Patience and Persistence}

Hans de Haze arrived in Aceh (1615) with a lot of cash and goods to push for a trade license in the ports on the west coast where Iskandar Muda's decrees did not allow the locals to trade with foreigners, according to Coen "as the Indian aphorism goes: the strongest is king". Coen's later actions in Jacatra (Jakarta) and Banda show that he used brutal force against the weaker ports. De Haze conveyed the message to the sultan that assistance for an attack of Malacca, as he requested, could not be provided, because the English were causing the company much trouble in Banda and no ships could be made available. A license to trade was of absolute necessity to provide the incomes to maintain a fleet in the Straits.

Iskandar Muda was not impressed, telling him that the English were licensed to trade in the ports. Adding to the refusal, seasonal floods had washed away the storerooms taking the goods with it, a serious financial loss for the company. On top of it merchant Rijsser was thrown to the elephants because he did not wait for the royal stamp to step ashore. De Haze closed the office and furtively left taking the merchants with him, a trespass of the local rule which was a serious offence to Iskandar Muda, who later communicated this to Coen. Interestingly, even after a year Coen sent his excuses to Iskandar Muda, accusing de Haze of uncivilised behaviour and the resident merchants of drinking too much arak. ${ }^{6}$ In pursuing his objectives, he unscrupulously blamed his merchants of improper behaviour, rightly or wrongly.

The following is quoted from a larger text: A fragment of paper, translated from Dutch, anonymous and imperfect:

The factory of Atchin if it had been used as it should have been, it would have been one of the principallest factories in India for the Company, but there hath always been no regard taken of it besides that it hath always been furnished with debauched persons which study more in the Arrack pot than to the company's good service, and so that factory will come to nought before any diligent and experienced person be sent, which will seek the Company's profit and not his own and which may be suffered to have a little in the going and coming ships. And also that it may be overseen by greater men of charge and that it be so used that Factory may have this yearly cargoson belonging thereto of Cloths, otherwise all will come to nothing. (Danvers and Foster 1896-1902, vol. 1, 77) 
Coen could be reflective as we notice in his letter of 1616 to Andries Soury, resident merchant in Jamby (translated from Dutch):

Excuse me for my condescending tone, ordering you as if you are incapable and not knowing what to say; as if the blind - who are blinded by their anxieties - lead those who can see, directing them the way. (Colenbrander 1919-1953, vol. II, 62)

Soury was instrumental in the efforts to keep the Portuguese and the Atchynder from Jambi. He was urged to gather information about their strategies and designs at whatever cost. The director-general of the company was adamant to have his feet firmly grounded in Sumatra.

The English occupied the vacated houses of the Dutch in Aceh after spreading the news that the merchants left for the Moluccan islands never to return. It added to a ruler's prestige when European merchants resided in his port. Coen vowed to take actions against anyone who damaged the interests of the company and the honour of Prince Maurice. He was determined to remain in Aceh. He scolded de Haze for having closed the Aceh factory. His credo was "we must be patient, for absence means losing our right".

A period of frantic communications with Iskandar Muda started. In 1616 two fleets in succession were dispatched to Aceh. The second one was endorsed with a special status. Coen appointed Cornelis Comans as the ambassador of governorgeneral Reynst to give the mission more dignity and authority. Up to that time the merchants acted as envoys.

The protocol of conduct prescribed that the hoisting of the flag should be from the largest ship in which the ambassador was sailing, to impress the sultan with the fact that the governor-general himself, the highest authority in the Indies, asked for a contract to trade on the west coast. Instructions concerned the exact number of men allowed to leave the ship for Coen wanted to take no risk in case of an Acehnese attack. A limit was set on the value of the gifts to be presented to Iskandar Muda, which depended on the conditions of the contract.

Coen even used the arrival of the fleet of admiral Verhagen in the Straits a year earlier in 1615 to seize a Spanish galleon coming from the Philippines and loaded with silver, as Iskandar Muda's request for assistance to attack Malacca. It was a deliberate twist of the truth. Verhagen, angered to learn of the devastation of Johor by the Acehnese - which was the second in two years - decided to go after the armada but ran instead into three Portuguese warships sheltering between the islets 
and attacked these. Verhagen handed over the seized artillery to Sultan Abdullah Ma'ayat Shah to defend himself against the Acehnese. Dutch preparedness to act against the Acehnese shows that there was at that time no coherent policy towards Aceh.

Interesting to mention in this context is, that the brass cannon known as Seri Rambai, standing proudly in Fort Cornwallis in Penang, made in the United Republic by Ian Bergerus (Jan Burgerhuis) from the town of Middelburg, was most probably presented by admiral Matelieff to Sultan Alau'd-din Ri'ayat Shah and Raja Bongsu of Johor. The translation by Dato F. Douglas of the engraving from the Jawi script says: "Captive of the Sultan. Taken by us Sri Perkasa Alam Johan Berdaulat (Iskandar Muda) when we ordered the laksamana ... to attack Johor in 1023 AH (1613)".

The above is supported by a witness report from the Bendahara of Johor, Tun Muhamad (Sri Lanang), the composer of the Malay Annals, who was a captive of Iskandar Muda and related the story of the Acehnese invasion to Sheikh Nuru'd-din al-Raniri, the composer of the Bustan as-Salatin (Douglas on "Notes on the historical geography of Malaya" as cited in Bradell 1980, 515).

It is suggested that the cannon was sent by the incumbent sultan of Aceh at the end of the 18th century to Selangor and taken by the British to Penang after they destroyed Selangor because pirates from there seized several junks on their way to Penang. The cannon is shrouded in legend which has acquired prominence. Yet in the historical context it is an example of how war loot is used as a symbol of, in this case, British indestructability.

While the cannon was presented by admiral Matelieff to the sultan of Johor to defend his country against the Portuguese, successive admirals later presented Sultan Abdallah Ma'ayat Shah with armoury seized from Portuguese ships to defend himself against Aceh. The Portuguese forced Sultan Abdallah, the vassal of Iskandar Muda, to sign another truce (1615). Johor was tethering at the edge of abyss. Sultan Abdallah left for a life in exile to Bintan in the Riau islands, fearing Iskandar Muda's reprisals which came shortly afterwards.

In the meantime, Comans, the wandering ambassador so to speak, sailed on Sumatra's west coast, designing plans to undermine Iskandar Muda, proposing to Coen an invasion of Malacca in cooperation with Aceh and once inside the city to capture the Acehnese and take the city for the VOC (Colenbrander 1919-1953, vol. VII, 396-400). During the past three years he sailed from Bantam to Aceh three times, expecting to be licensed as Iskandar Muda had promised, instead he 
extended the license of the English. He finally received the license in 1619 with barely acceptable conditions, i.e., the sultan was the first buyer of pepper in the ports and the left overs of lesser quality could be procured within a very limited period. Bartering pepper against textiles which was usually the norm and much preferred, was no longer possible, because Iskandar Muda paid for his pepper with textiles confiscated from the subdued Malay port of Kedah (1619). He had to pay in cash. The locals demanded a higher price than Comans offered, which he refused to pay and departed for Bantam without one peppercorn. Coen without consideration sacked Comans from the company's service, accusing him of gross negligence of the business.

Earlier Rajah Lele, a chief of the port of Priaman approached Comans with a request for assistance to oust the Acehnese tyrant from his port, whereupon Comans asked Coen to send a small fleet to this cause. Iskandar Muda's intelligence seemed to work well for he immediately started constructing a defensive wall in Priaman. The proposals were not implemented, even though Coen earlier instructed Comans to invade Priaman in case the Atchynder refused him a license to trade there. This ambivalence marked Coen's conduct towards Aceh, the overlord of the ports. Coen had set eyes on Jacatra as the company's future headquarters, as the sequel shows, which made the conquest of Malacca redundant. It would be interesting to know if the 12 years truce (1609-1621) with Spain made him deviate from the erstwhile objective to conquer Malacca. Was it his Calvinist upbringing that instilled in him obedience towards a higher authority such as the Gentlemen XVII and Prince Maurice? Or was Malacca no longer the dreamed Valhalla that drew all energy and concentration?

But why not invade Priaman when he regarded Iskandar Muda worse than the Pangeran of Bantam, for he drew all the pepper from the ports to the port of Aceh to sell this at his own convenience. He whimpered disparagingly "the Atchijnder may rant and brawl, but in the end he shall be defeated. He regards us as his slaves. With God's help the pages shall turn" (Colenbrander 1919-1953, vol. I, 40). He made retreating moves, even when big words filled the offices in Bantam and later in Batavia, and instructions full of rhetoric were passed to the merchants and messengers to the court of Aceh.

The locals in the port of Tiku on Sumatra's west coast, murdered merchant Rassiere (1618) because he was brash. Coen immediately demanded justice and compensation from Iskandar Muda whereupon two innocent slaves were accused of the murder and would be executed if the Dutch merchants had not intervened on their behalf. 
Coen switched from one strategy to another, leaving the merchants confused by his erratic decisions which made it difficult for them to deal with the locals. His strategies seemed rooted in instinct and impulsiveness. A charm offensive came into place; the merchants found themselves showering the locals in Tiku with cash and gifts, in fact putting these people's lives at risk because Iskandar Muda threatened to chop off their heads if they traded with foreigners.

From the correspondence produced during this period, between the authorities in the Indies and the Gentlemen XVII, it is understood that Malacca was too costly to conquer and unsuitable as a trade centre. However, the Portuguese still formed a threat to Dutch interests. Comans seized a Portuguese vessel and handed the weapons and ammunition to Abdallah of Johor to defend himself against the Acehnese. He lifted goods from a Chinese junk and Muslim vessels for which he had to pay the market price following the instructions from Coen regarding goods lifted from local vessels (Colenbrander 1919-1953, vol. II, 262-263).

In 1619 Coen established the headquarters of the VOC on the ashes of Jacatra, the town he burnt down and renamed it Batavia. He was appointed as GovernorGeneral of the Indies (1619-1623; second-term appointment 1624-1627).

In 1620 the signing of the Anglo/Dutch Defence Treaty for the Indies made the two European rivals allies in the trade; it was a turning point in their overseas activities. They operated closely to put Iskandar Muda under pressure to drop his price for pepper. It reminds us of an old saying, "one has to behave as friend or foe according to circumstances".

It was to no avail, Iskandar Muda was not amused with the alliance of erstwhile foes and even threatened to throw them out of his country, calling them the beggars of Europe who were shameless. He yelled at them that he was as much a king as the king of Holland and the king of England. Did they think that he did not possess enough gold and silver and depended on them? He challenged them by saying, "If you want war, I am ready for it; if you come with 70 ships I will bring 600 and assemble all the people of Aceh and bring them to the west coast" (Colenbrander 1919-1953, vol. II, 614-617).

Coen had been fiercely against the treaty with the English for they received a third part of the profits made in the Moluccan islands while they refused to take actions against the Iberians in Banda. aHe warned the Gentlemen XVII that they were nurturing a serpent in their bosom (Colenbrander 1919-1953, vol. I, 543-544). 
As the alliance foresaw no easy trading in Aceh they decided to leave in 1622. It made Iskandar Muda furious, for although he haughtily told them to knock on another door, he needed foreign traders in his port. He knew that Jambi was an attractive port to procure pepper. He threatened to sack Jambi in 1624 because, as the report goes, the widow and young son of Sultan Abdallah had taken refuge there after Abdallah died in 1623 in exile of what the Dutch called "a broken heart". He did not follow up on his threat, facing a large and very mixed opposition. Instead he deviated his attention to Malacca, starting its siege in 1626 . He suffered a humiliating defeat in 1629 when the Portuguese closed off the river in which the complete armada had entered. Patani and Johor came to the support of the Portuguese by sending their fleets. The Portuguese seized the giant flagship Cakra Dunya, wheel of the world, which they called "terror of the world", bringing it to a safe haven in Goa. They were euphoric with their victory. The armada was decimated. The attack and the Portuguese reactions to it are described by Boxer in "The Achinese attack on Malacca in 1629" (Bastin and Roolvink 1964).

It was extremely worrying for the Dutch to see the Portuguese getting hold of the huge amount of Acehnese armoury and ships, strengthening their military capacity. They had been totally overwhelmed by the events. However, three years had passed since the siege started and they did not come to Iskandar Muda's help.

The VOC merchants in Patani advocated to renew the old friendship with Aceh and conduct a joint military operation to attack Malacca, apparently alerted by the fact that Portuguese vessels frequented the port. Important for understanding the political realities is the fact that earlier the queen of Patani made a request (1620) to the governor-general in Batavia, not to act against the Portuguese in her territorial waters and against her ships going to Malacca and the Moluccan islands. Coen replied that he liked to see her continue to drive the Portuguese away from her port, but he would not seize her ships going to Malacca and the Moluccan islands (Colenbrander 1919-1953, vol. I, 613). Patani several times succoured Malacca against Aceh. Years later in 1636 governor-general Brouwers remarked "Patani is the friend of our enemy and the enemy of our friend".

Aceh remained a power factor to reckon with, even after the loss of its armada, it was not attacked by its enemies. After he sacked Johor, Pahang, Perak and Kedah successively between 1613 and 1620, confiscating their vessels and artillery and capturing thousands of their people, Iskandar Muda deflated the possibilities for counter attacks (Mitrasing 2011, 175-215).

Coen's successor, governor-general Carpentier, was less patient with Iskandar Muda; he was brooding on a plan to encircle the Atchijnder on the west coast 
of Sumatra with ships and take the ports for the VOC, if he refused to sign a friendship agreement (Coolhaas 1966, vol. I, 144-145). He deviated from the policy of his predecessors, desirous to leave his mark as a strong administrator. The confrontation with Iskandar Muda did not happen.

The delegation of Stadtlander to Iskandar Muda in 1632 proposed a joint military strike of Malacca in return for trade contracts. The victory of the Portuguese was cause for the parties to renew the relations; bad thoughts gave away to the sense that a new beginning was looming. But why not cooperate together to dispel the Portuguese from Malacca without pre-conditions? Thirty years had passed-by and the alliance had come to nothing.

It came as a shock to the Dutch when they arrived in 1634 in Indrapura, a port in the far south of the west coast, to discover that Iskandar Muda had introduced mooring taxes in the port. He would not budge, had all the pepper vines cut down and brought the loot to the port of Tiku, leaving the message that the merchants could buy pepper in Tiku.

In spite of this new hurdle the VOC's renewed friendship with Iskandar Muda paid off; that same year it booked a profit of 47,369 Dutch florins for trade on the west coast. The profit of one voyage to the port of Aceh amounted to 3,874 florins (Mitrasing 2011, 475).

The years leading up to the conquest of Malacca by the VOC in 1641 were marked by frantic diplomacy between Batavia and Aceh, and Batavia and Johor for a joint attack of Malacca. Governor-general Antonio van Diemen was adamant to conquer Malacca for the VOC and needed the assistance of Aceh as earlier agreed. He laid down his ambitious plan for a broad coalition which included Johor.

Since 1637, captains, admirals and diplomats were arriving at the court of Sultan Iskandar Thani (r. 1637-1641), to induce him to cooperate, because he flatly refused to be included in a coalition in which his arch enemy Johor was participating; he was a captured prince of Pahang. He called it betrayal. He suggested that the governor-general cut all ties with Johor: "If the Almighty Lord permits, the Dutch and Aceh Daru's Salam shall together besiege Malacca as if they are of one blood, united in arms to dispel the enemy" (van der Chijs 1887, 6-9).

Van Diemen responded that he wanted to disentangle Johor from Malacca by taking Johor under his wings. His reasons went beyond gaining Johor's loyalty; in his letter of 9 December 1637 to the Gentlemen XVII he wrote: "The company should not allow the Indian princes to become big by supplying them with Dutch 
artillery, but to keep them in balance against one another", suggesting to call on all of them to combine forces against the Portuguese, relieving the company of high costs (Coolhaas 1966, 605). He asked Iskandar Thani to contribute gunpowder for the attack. Aceh possessed the raw material to produce gunpowder (Takeshi 1984, $71)$.

The two Acehnese delegations that went to Batavia in brief succession to explain their ruler's stance, were received with great respect and the shooting of muskets in their honour, but van Diemen's answer was firm: Johor could not be excluded.

In a desperate effort to keep the Dutch on his side, Iskandar Thani wrote to Prince Frederick Hendrik, the brother and successor of Prince Maurice, not to forsake him but to keep the brotherly bond "as in the time of the late Iskandar Muda. Like a golden chain that cannot break". ${ }^{7}$

He feared an attack by the Dutch and Johor and ordered the building of a dam in the river on the west side of his city and had a canal dug for the convenience of his people. Malacca fell to the VOC in 1641 with some help of Johor.

\section{Finally}

The nature of the partnerships changed with regard to the different ports. Friendship with Johor was genuine and lasting. Patani was crucial for its trade in pepper and silk and its access to the South China Sea.

In its relations with Aceh the notion of a powerful ally against the common enemy in Malacca was the rationale. Keeping a "dead friendship" discouraged war between them.

\section{Notes}

1. Both journals are published in Unger (1948), De Oudste Reizen van de Zeeuwen.

2. The VOC later paid the sultan fort the losses he had suffered.

3. Nationaal Archief (National Archives) 1.11.01.01: 152: 1873 Facsimile of a Letter of Prince Maurice (11 December 1600); see also Banck $(1873,23)$.

4. The prince was called upon by the States General of the United Republic to act as sovereign in the communications with Asian monarchs.

5. Nationaal Archief (National Archives) VOC: 1.04.02: 11263: Copie van een brief van de sultan van Aceh aan Prince Maurice (1610).

6. A distilled beverage from palm juice, rice or sugar cane.

7. Nationaal Archief (National Archives) VOC: 1.04.02: 11264: Translaet van een brief van de sultan van Aceh aan Prince Frederick Hendrik (1637). 


\section{References}

Banck, J.E. 1873. Atchin's Verheffing en Val. Rotterdam: Nijgh en Van Ditmar.

Bastin, J. and Roolvink, R. (eds.). 1964. Malayan and Indonesian studies: Essays presented to Sir Richard Winstedt on his eighty-fifth birthday. Oxford: Clarendon Press.

Birdwood, G. (ed.). 1893. The register of letters of the governor and company of merchants of London trading into the East Indies 1600-1619. London: Quatrich.

Boxer, C.R. 1965. The Dutch seaborne empire 1600-1800. London: Hutchinson. 1964. The Acehnese attack on Malacca in 1629 as described in contemporary Portuguese sources. In Malayan and Indonesian studies: Essays presented to Sir Richard Winstedt on his eighty-fifth birthday, eds. J. Bastin and R. Roolvink. Oxford: Clarendon Press.

Bradell, R. (ed.). 1980. The study of ancient times in the Malay Peninsula and Straits of Malacca, and notes of ancient times in Malaya. Kuala Lumpur: Malaysian Branch of the Royal Asiatic Society (MBRAS).

Chijs, J.A. van der (ed.). 1887. Dagh-Register uit Casteel Batavia anno 1640-1641. 's-Gravenhage: Martinus Nijhoff.

Colenbrander, H.T. (ed.). 1919-1953. Coen's Bescheiden Omtrent Zijn Bedrijf in Indie (7 volumes in 8 parts). 's-Gravenhage: Martinus Nijhoff.

Coolhaas, W.Ph. 1966. Generale Missiven van gouverneurs-generaal en raden aan Heren XVII der Verenigde Oostindische Compagnie (11 vols.). 's-Gravenhage: Martinus Nijhoff.

Danvers, F.C. and Foster, W. (eds.). 1896-1902. Letters received by the East India Company from its servants in the East (6 vols.). London: S. Low, Marston \& Company Ltd.

Davis, J. 1880. The voyages of John Davis the navigator London: Hakluyt Society.

Foster, W. 1940. The voyages of Sir James Lancaster to Brazil and the Indies 1591-1603. London: Hakluyt Society.

Gaastra, F. 2002. De Geschiedenis van de VOC. Zutphen: Walburg Pers.

Heeres, J.E. (ed.). 1907. Corpus Diplomaticum Neerlando Indicum (6 vols.). Leiden: BKI.

Houtman, F. de 1880. Cort Verhael van 'tgene wedervaren is Frederick de Houtman tot Atchein. Gouda: Van Goor.

Ittersum, M. van. 2006. Profit and principle Hugo Grotius, natural rights theories and the rise of Dutch power in the East Indies (1595-1615). Leiden: Brill.

Jonge, J.K.J. de. 1865-1964. De Opkomst van het Nederlandsch Gezag in Oost-Indie (3 vols.). Den Haag: Martinus Nijhoff.

Leupe, P.A. 1936. The siege and capture of Malacca from the Portuguese in 1640-1641. Journal of the Malayan Branch of the Royal Asiatic Society (JMBRAS) 14(1): i-iii, $1-178$.

Lobato, M. 2000. Malacca. In Historia dos Portugeuses no Extremo Oriente (vol. I, part II), ed. A.H. de Oliveira Marques. Lisbon: Fundacao Oriente.

Lombard, D. 1967. Le Sultanat d'Atjeh au temps d'Iskandar Muda 1607-1636. Paris: Ecole Francaise d'Extreme Orient.

(ed.). 1996. Memoires d'un voyage au Indes Orientales 1619-1621 Augustin de Beaulieu un marchand normand a Sumatra. Paris: Maison Neuve et Larose. 
Marques, A.H. de O. (ed.). 2000. Historia dos Portugeuses no Extremo Oriente (vol. I, part II) Lisbon: Fundacao Oriente.

Meilink-Roelofsz, M.A.P. 1962. Asian trade and European influence in the Indonesian archipelago between 1500 and about 1630. 's-Gravenhage: Martinus Nijhoff.

Mitrasing, I.S. 2011. The age of Aceh and the evolution of kingship 1599-1641. PhD dissertation, Leiden University.

Spilbergen, J. van. 1933. De Reis van Joris van Spilbergen naar Ceylon, Atjeh en Bantam, 1601-1604 (vol. XXXVIII). Pijnacker: Linschoten Vereeniging.

Takeshi, I. 1984. The world of the Adat Aceh. Canberra: Australian National University.

Tiele, P.A. 1877. De Europeers in den Maleischen Archipel. Bijdragen tot de Taal-, Landen Volkenkunde (BKI) xxv. 's-Gravenhage: Martinus Nijhoff.

1886. Bouwstoffen voor de Geschiedenis der Nederlanders in den Maleischen Archipel (vol. 1). 's-Gravenhage: Martinus Nijhoff.

Unger, W.S. (ed.). 1948. De oudste reizen van de Zeeuwen naar oost-Indië 1598-1604. 's-Gravenhage: Martinus Nijhoff.

Wap, P. 1862. Het Gezantschap van de sultan van Atchin (1602) aan Prins Maurits van Nassau. Rotterdam: Nijgh.

Winstedt, R.O. 1932. A history of Johore. Journal of the Malayan Branch of the Royal Asiatic Society (JMBRAS) 10(3): 1-167. 